\title{
DAMPAK MAKRO EKONOMI TERHADAP INDEKS HARGA SAHAM \\ GABUNGAN DI INDONESIA
}

Oleh :

Rutinaias Haholongan

Sekolah Tinggi Ilmu Ekonomi Indonesia Jakarta

Email : rutinaias@gmail.com

Apry Linda Diana

Email : aprylindadiana@gmail.com

\begin{tabular}{l}
\hline Article Info \\
\hline Article History : \\
Received 29 August - 2021 \\
Accepted 05 Sept - 2021 \\
Available Online 25 Sept - \\
2021
\end{tabular}

Keyword:

GDP, Exchange rate,

Interest rate, IHSG

\section{PENDAHULUAN}

Dalam aktivitas dipasar modal, para investor memiliki harapan dari investasi yang dilakukannya, yaitu yang berupa capital gain dan dividen. Kebijakan pembayaran dividen mempunyai pengaruh bagi pemegang saham dan perusahaan yang membayar dividen. Para pemegang saham umumnya menginginkan pembagian dividen yang relatif stabil karena hal tersebut akan mengurangi ketidakpastian akan hasil yang diharapkan dari investasi yang mereka lakukan dan juga dapat meningkatkan kepercayaan pemegang saham terhadap perusahaan, sehingga nilai saham juga dapat meningkat. Bagi perusahaan, pilihan untuk membagikan laba dalam bentuk dividen akan mengurangi sumber dana internalnya, sebaliknya jika perusahaan menahan labanya dalam bentuk laba ditahan maka kemampuan pembentukan dana internalnya akan semakin besar yang dapat digunakan untuk membiayai aktivitas perusahaan sehingga mengurangi ketergantungan perusahaan terhadap dana eksternal dan sekaligus akan memperkecil 
resiko perusahaan. Aktivitas investasi merupakan aktivitas yang dihadapkan pada berbagai macam resiko dan ketidakpastian yang sering kali sulit diprediksikan oleh para investor. Untuk dapat mengurangi kemungkinan resiko dan ketidakpastian tersebut maka investor memerlukan berbagai ilmu dan pengetahuan mengenai berbagai investasi yang baik, yang akan mendatangkan keuntungan bagi para pemegang saham. Investasi adalah penanaman modal untuk satu atau lebih aktiva yang dimiliki dan biasanya berjangka waktu lama dengan harapan mendapatkan keuntungan dimasa-masa yang akan datang (Dornbusch, 2018).

Dari beberapa alternatif investasi yang ada, investasi di pasar modal menjadi salah satu pilihan para pemegang saham dalam menanamkan sahamnya. Alternatif investasi yang dapat ditanamkan di pasar modal dapat berupa saham, obligasi, ataupun berbagai surat berharga lainnya. Pada umumnya para investor mempunyai tujuan utama dalam menanamkan dananya di pasar modal, yaitu untuk mencari pendapatan atau return baik berupa pendapatan dividen (dividend yield) maupun pendapatan dari selisih harga jual saham terhadap harga belinya (capital gain). Tingkat keuntungan yang diharapkan haruslah lebih besar daripada bila mereka menanamkan dananya pada obligasi pemerintah atau tingkat deposito dilain pihak, perusahaan juga mengharapkan adanya pertumbuhan secara terus menerus untuk mempertahankan kelangsungan hidupnya, yang sekaligus juga harus memberikan kesejahteraan yang lebih besar pada para pemegang sahamnya (Dornbusch, 2018). Masalah pertumbuhan ekonomi dapat dipandang sebagai masalah makroekonomi dalam jangka panjang. Dari satu periode ke periode lainnya kemampuan suatu negara untuk menghasilkan barang dan jasa akan meningkat. Kemampuan yang meningkat ini disebabkan karena faktor-faktor produksi akan selalu mengalami pertambahan dalam jumlah dan kualitasnya. Penambahan faktor-faktor produksi ini dapat terwujud melalui investasi.

Samuelson (2015) menyatakan bahwa sumber daya yang akan digunakan untuk meningkatkan pendapatan dan konsumsi dimasa yang akan datang disebut sebagai investasi. Dengan demikian investasi dapat diartikan sebagai pengeluaran atau perbelanjaan penanam-penanam modal atau perusahaan membeli barang-barang modal dan perlengkapan-perlengakapan produksi untuk menambah kemampuan memproduksi barangbarang dan jasa-jasa yang tersedia dalam perekonomian. Kondisi ekonomi dalam negeri maupun kondisi ekonomi secara global memberikan warna tersendiri bagi fluktuasi pergerakan IHSG. Fluktuasi IHSG sebagian besar diakibatkan oleh kejadian-kejadian di luar factor fundamental perusahaan, seperti keadaan makroekonomi yaitu Produk Domestik Bruto (PDB), laju inflasi, tingkat suku bunga dan nilai tukar mata uang/ kurs (Granger, 2011).

Selain GDP nilai tukar rupiah atau kurs juga dapat mempengaruhi pertumbuhan ekonomi. Menurut kewal (2014) nilai tukar atau kurs adalah perbandingan nilai atau harga antara dua mata uang yang berbeda. Penentuan kurs valuta asing merupakan hal yang penting bagi pelaku bursa valas, karena kurs valas sangat mempengaruhi jumlah biaya yang harus dikeluarkan serta besarnya manfaat (keuntungan) yang akan diperoleh dalam transaksi barang, jasa dan surat berharga yang berlangsung dibursa valas. Kurs merupakan salah satu alat untuk kebijakan ekonomi bagi sebuah negara. Penurunan dan kenaikan perekonomian Indonesia bisa dilihat dari pergerakan nilai mata uang rupiah. Naik turunnya pasar modal suatu negara tidak terlepas dari ekonomi makro negara tersebut sehingga indikator-indikator ekonomi makro bisa memberikan kontribusi yang positif atau bahkan negative terhadap pasar modal. Pernyataan ini diperkuat oleh kewal (2014) yang menyatakan bahwa variable ekonomi makro memiliki keterkaitan erat dengan return saham. Pengaruh ekonomi makro menurut kewal (2014) akan berdampak terhadap proses perdagangan saham, hal ini dikarenakan ekonomi makro dapat mempengaruhi prospek perusahaan di masa depan seperti dalam hal tingkat keuntungan. Seperti yang dijelaskan oleh teori ekonomi bahwa harga saham seharusnya mencerminkan harapan terhadap tingkat kinerja perusahaan di masa akan datang, dan tingkat keuntungan perusahaan mencerminkan tingkat kegiatan ekonomi.

\section{KAJIAN PUSTAKA DAN PENGEMBANGAN HIPOTESISI Gross Domestic Product (GDP)}

Gross Domestic Product (GDP) adalah nilai keseluruhan barang dan jasa yang diproduksi di dalam wilayah tersebut dalam jangka waktu 
tertentu (biasanya per tahun). PDB berbeda dari produk nasional bruto karena memasukkan pendapatan faktor produksi dari luar negeri yang bekerja di Negara tersebut. Sehingga PDB hanya menghitung total produksi dari suatu negara tanpa memperhitungkan apakah produksi itu dilakukan dengan memakai faktor produksi dalam negeri (Samuelson dan Nordhaus, 2015).

Tipe GDP dibagi menjadi 2 yaitu dengan harga berlaku atau GDP nominal dan harga tetap atau GDP riil. Menurut Samuelson dan Nordhaus (2015) pendapatan agregat sama dengan penjumlahan semua pendaptan yang diterima pemilik sumber daya dalam perekonomian (karena sumber dayanya digunakan dalam proses produksi). Sistem pembukuan doubleentry dapat memastikan bahwa nilai output agregat sama dengan pendapatan agregat yang dibayarkan untuk sumber daya yang digunakan dalam produksi output tersebut: yaitu upah, bunga, sewa, dan laba dari produksi. Nilai tambah dari tiap tahap mencerminkan pendapatan atas pemilik sumber daya pada tahap yang bersangkutan. Penjumlahan nilai tambah pada semua tahap produksi sama dengan nilai pasar barang akhir, dan penjumlahan nilai tambah seluruh barang dan jasa akhir adalah sama dengan GDP berdasarkan pendekatan pendapatan.

\section{Suku Bunga}

Suku bunga yang rendah akan menyebabkan biaya peminjaman yang lebih rendah. Suku bunga yang rendah akan merangsang investasi dan aktivitas ekonomi yang akan menyebabkan harga saham meningkat(Awudu,2014). Dalam dunia properti, suku bunga berperan dalam meningkatkan aktivitas ekonomi sehingga berdampak kuat pada kinerja perusahaan properti yang berakibat langsung pada meningkatnya return saham.

Suku bunga Sertifikat Bank Indonesia sering diidentikan dengan aktiva yang bebas risiko artinya aktiva yang risikonya nol atau paling kecil. Semakin kecil suku bunga Bank Indonesia maka semakin besar risiko sistematik saham.(Lestari,2014). Suku bunga bank Indonesia merupakan patokan dalam menentukan besarnya bunga kredit dan tabungan. Suku bunga SBI yang tinggi tidak menggairahkan perkembangan usaha - usaha karena mengakibatkan suku bunga bank yang lain juga tinggi. Sehingga rendahnya suku bunga SBI mengandung risiko lesunya ekonomi. Hal ini mengakibatkan tingginya risiko berinvestasi di pasar modal.

BI Rate adalah suku bunga kebijakan yang mencerminkan sikap kebijakan moneter yang ditetapkan oleh Bank Indonesia dan diumumkan kepada public. Bank Indonesia memiliki tugas sebagai otoritas moneter yaitu membantu pemerintah dalam mengatur, menjaga, memelihara kestabilan nilai Rupiah.

\section{Nilai Tukar Rupiah}

Menurut Smith(2010) Nilai tukar suatu mata uang adalah harga mata uang suatu negara terhadap negara asing lainya, misalnya harga dari satu dollar Amerika saat ini . Nilai tukar atau lazim juga disebut kurs valuta dalam berbagai transaksi ataupun jual beli valuta asing, dikenal ada empat jenis yakni Tandelin (2012):

a. Selling Rate (kurs jual), yakni kurs yang ditentukan oleh suatu Bank untuk penjualan valuta asing tertentu pada saat tertentu

b. Middle Rate (kurs tengah), adalah kurs tengah antara kurs jual dan kurs beli valuta asing terhadap mata uang nasional, yang ditetapkan oleh Bank Central pada suatu saat tertentu.

c. Buying Rate (kurs beli), adalah kurs yang ditentukan oleh suatu bank untuk pembelian valuta asing tertentu pada saat tertentu.

d. Flat Rate (kurs flat), adalah kurs yang berlaku dalam transaksi jual beli bank notes dan traveller chaque, di mana dalam kurs tersebut sudah diperhitungkan promosi dan biaya biaya lainya.

Kurs merupakan salah satu harga yang terpenting dalam perekonomian, mengingat pengaruh yang demikian besar bagi neraca transaksi berjalan maupun variabel-variabel makro ekonomi yang lain. Ada dua pendekatan yang digunakan untuk menentukan nilai tukar mata uang yaitu pendekatan moneter dan pendekatan pasar(Damele et all,2012)

\section{Indek Harga Saham Gabungan (IHSG)}

Dasar perhitungan IHSG adalah jumlah nilai pasar dari total saham yang tercatat. Jumlah nilai pasar adalah total perkalian setiap saham tercatat kecuali untuk perusahaan yang berada dalam program restrukturisasi dengan harga di BEI pada hari tersebut (BEI, 2010). Ada beberapa macam pendekatan atau metode perhitungan yang digunakan untuk menghitung indeks, yaitu: (1) menghitung rata-rata 
(arithmetic mean) harga saham yang masuk dalam anggota indeks, (2) menghitung (geometric mean) dari indeks individual saham yang masuk anggota indeks, (3) menghitung rata-rata tertimbang nilai pasar.

Melalui display wall di lantai bursa dan disebarkan ke masyarakat luas oleh data vendor melalui data feed. Dewasa ini Indeks Harga Saham dijadikan barometer kesehatan ekonomi di suatu negara dan juga sebagai landasan analisis statistik atas pasar terakhir. Fenomena ekonomi tersebut meliputi mikro dan makro ekonomi. Fenomena makro diantaranya perubahan nilai tukar, suku bunga, tingkat inflasi. Perubahan harga saham setiap hari perdagangan akan membentuk IHSG. Angka indeks dibuat sedemikian rupa hingga dapat digunakan untuk mengukur kinerja saham yang dicatat di bursa efek, dimana return dan risiko pasar tersebut dihitung. Return portofolio diharapkan meningkat jika IHSG cenderung meningkat, demikian sebaliknya return tersebut menurun jika IHSG cenderung menurun. Bahkan saat ini IHSG dapat dijadikan barometer yang menunjukkan kesehatan ekonomi suatu negara dan dapat sebagai dasar dalam menganalisis kondisi pasar (Ria 2013). Apabila terjadi peningkatan IHSG maka kondisi pasar bagus. IHSG digunakan oleh investor dalam melihat kondisi bursa yang akan digunakan untuk mengambil suatu keputusan saat melakukan transaksi saham. IHSG berlaku untuk saham individu/kelompok sedangkan harga saham gabungan IHSG menggunakan data semua saham yang tercatat di suatu bursa efek.

\section{METODE PENELITIAN}

Populasi adalah jumlah keseluruhan dari unit analisis yang ciri-cirinya akan diduga. Populasi dapat dibedakan antara populasi sasaran (target) dan populasi terjangkau. Dalam penelitian ini, populasi sasaran (target) adalah Indek Harga Saham Gabungan di Bursa Efek Indonesia, sedangkan populasi terjangkau adalah GDP, Suku Bunga, Nilai Tukar tahun 2015 - 2019.

Teknik pengumpulan data yang dipergunakan adalah dengan melakukan pencatatan langsung berupa data time series (tahunan). Metode penarikan sampel yang digunakan pada penelitian ini adalah Indek Harga Saham Gabungan di BEI antara tahun 2015-2019. GDP (Gross Domestik Product) Produk domestik bruto adalah keseluruhan nilai produksi barang dan jasa yang dihasilkan oleh suatu negara dalam periode tertentu biasanya 1 tahun. Di mana GDP yang digunakan dalam penelitian ini adalah GDP Indonesia dengan harga konstan pada periode 2015-2019 Suku bunga menggunakan pengukuran skala menggunakan rata- rata SBI 1 bulanan Perhitungan nilai tukar yang digunakan adalah nilai dollar Amerika Serikat terhadap rupiah secara bulanan. Nilai tengah antara kurs jual dan beli yang digunakan oleh Bank Indonesia yang diterbitkan bulanan. \I

Metode analisis data yang digunakan dengan adalah analisis regresi berganda. Pengujian hipotesis menggunakan uji $\mathrm{t}$ dan koefisien determinasi. Taraf signifikansi yang digunakan adalah $5 \%$

\section{HASIL DAN PEMBAHASAN \\ Tabel 1}

Hasil pengujian Koefesien Determinasi

GDP, Nilai tukar, Suku bunga

Terhadap IHSG Periode 2015-2019

\begin{tabular}{cccccr}
\hline Model & $\mathrm{R}$ & $\begin{array}{c}\mathrm{R} \\
\text { Square }\end{array}$ & $\begin{array}{c}\text { Adjusted } \\
\mathrm{R} \\
\text { Square }\end{array}$ & $\begin{array}{c}\text { Std. } \\
\text { Error of } \\
\text { the } \\
\text { Estimate }\end{array}$ & $\begin{array}{c}\text { Durbin- } \\
\text { Watson }\end{array}$ \\
\hline 1 & $.867^{\mathrm{a}}$ & 0.751 & 0.743 & 1.78426 & 2.467 \\
\hline
\end{tabular}

Dari hasil perhitungan diperoleh hasil besarnya pengaruh variabel independen terhadap variabel dependen yang dapat diterangkan oleh model persamaan ini adalah sebesar 74,3\%. Hal ini menunjukkan bahwa besar pengaruh GDP, Nilai tukar, Suku bunga terhadap IHSG yang dapat diterangkan oleh model persamaan ini adalah sebesar 74,3\% dan sisanya sebesar $25,7 \%$ dipengaruhi oleh faktorfaktor lain yang tidak dimasukkan dalam model regresi, seperti faktor ekonomi negara secara makro, faktor sentimen pasar serta faktor politik negara.

Tabel 2

Hasil Uji T GDP, Nilai Tukar, Suku Bunga Terhadap IHSG Periode 2015-2019

\begin{tabular}{|c|c|c|c|c|c|c|}
\hline & & $\begin{array}{r}\text { Unstan } \\
\text { Coeff } \\
\end{array}$ & $\begin{array}{l}\text { ardized } \\
\text { ients }\end{array}$ & $\begin{array}{c}\text { Standardized } \\
\text { Coefficients }\end{array}$ & & \\
\hline & del & B & $\begin{array}{l}\text { Std. } \\
\text { Error }\end{array}$ & Beta & $\mathrm{t}$ & Sig. \\
\hline 1 & (Constant) & 1.329 & 1.106 & & 1.202 & 0.232 \\
\hline & $\begin{array}{l}\text { Nilai } \\
\text { Tukar }\end{array}$ & 0.087 & 0.065 & 0.101 & 1.331 & 0.186 \\
\hline & $\begin{array}{l}\text { Suku } \\
\text { Bunga }\end{array}$ & 0.270 & 0.085 & 0.273 & 3.191 & 0.002 \\
\hline & GDP & 0.549 & 0.080 & 0.563 & 6.841 & 0.000 \\
\hline
\end{tabular}


Nilai tukar tidak berpengaruh positif signifikan terhadap indek harga saham gabungan dengan nilai signifikansi 0,186>0,05. Harga saham tidak mempengaruhi nilai tukar uang melalui permintaan uang (money demand equation) yang membentuk suatu basis model alokasi portofolio dan moneter dari determinasi nilai tukar uang. Disamping itu harga saham dapat mencerminkan variabel makroekonomi, karena menunjukkan ekspektasi pasar terhadap aktivitas ekonomi riil Semenjak model nilai tukar uang misalnya model moneter mengkorelasikan nilai tukar tersebut terhadap variabel makro ekonomi, maka perubahan dalam harga saham dapat menyebabkan tidak berpengaruhnya dari nilai tukar.

Suku bunga berpengaruh positif signifikan terhadap Indek Harga Saham Gabungan menunjukkan bahwa nilai $t$ sebesar 3,191 dengan signifikansi 0,002 <0,000. Suku bunga memeiliki pengaruh terhadap kenaikan atau penurunan IHSG baik secara langsung maupun secara tidak langsung. Ketika suku bunga yang ditetapkan oleh Bank Indonesia naik, maka pada dasarnya akan menaikkan suku bunga kredit yang dikeluarkan oleh bank. Dengan meningkatnya suku bunga kredit maka akan mempengaruhi permintaan akan kredit properti (subprime mortgage). Dengan naiknya suku bunga kredit akan mempengaruhi permintaan akan properti yang nantinya akan mempengaruhi kinerja perusahaan properti yang terdaftar pada indeks saham gabungan

GDP berpengaruh positif signifikan terhadap IHSG, menunjukkan bahwa nilai $t$ sebesar 6,841 dengan signifikansi $0,000<0,05$, IHSG menunjukan peningkatan mengindikasikan bahwa kondisi perekonomian indonesia berada dalam siklus membaik, Semakin tinggi GDP maka semakin bagus pertumbuhan ekonomi tersebut. Pertumbuhan GDP yang cepat merupakan indikasi terjadinya pertumbuhan ekonomi di suatu Negara, Jadi dengan meningkatnya GDP maka akan menyebabkan permintaan konsumen meningkat dan mengakibatkan penjualan akan naik sehingga kinerja perusahaan akan meningkat. Hal tersebut akan menaikkan Indeks harga saham.

\section{KESIMPULAN}

Berdasarkan pada hasil-hasil analisis yang telah dilakukan sebelumnya, maka dapat ditarik beberapa kesimpulan sebagai berikut:

a. GDP berpengaruh terhadap Indek harga saham gabngan

b. Suku Bunga berpengaruh terhadap Indek harga saham gabungan

c. Nilai Tukar tidak berpengaruh terhadap Indek harga saham gabungan

\section{REFERENSI}

Awudu Yakubu.(2014). Relationship between stock market performance and macroeconomic variables in Ghana, Business management Vol.2

Damele, Manjri., Yamini Karmakar dan G Kawadia. (2012). A study of market Integration based on Indian Stock Market, Bullion Market and Foreign Exchange Market”. Finance India.Vol. XVII, No.2

Dornbusch, S. And R.Startz Fisher.(2018). Macroeconomics. Seventh Edition. McGraw- Hill,New York. Fama, E., dan French, K. "Business Condition and Expected Return on stocks and bonds".

Granger, C.W.J., Bwo-Nung, H., Yang, C.W.(2011). A Bivariate Causality Between Stock

Prices and Exchange Rates: Evidence from Recent Asia Flu. The Quarterly Review of Economics and Finance, 40, 337-54.

Jogiyanto.(2006) Teori Portofolio dan Analisis Investasi, BPFE UGM. Yogyakarta

Kewal,Suramayasuci.(2014). Pengaruh Inflasi,suku bunga, kurs dan perumbuhan PDB terhadap Indeks Harga Saham Gabungan. Jurnal Economia,volume 8

Lestari, M.(2014). Pengaruh Variabel Makro terhadap Return Saham di Bursa Efek Jakarta: Pendekatan Beberapa model. SNAVIII Solo, 15-16 September 2014

Ria Astuti, A. E. (2013). Analisis Pengaruh Tingkat Suku Bunga (SBI), Nilai Tukar (Kurs) Rupiah, Inflasi, dan Indeks Bursa Internasional Terhadap IHSG (Studi Pada IHSG di BEI Periode 2008 - 2012). Dipenogoro Journal Of Social And Politic Of Science Tahun 2013, Hal $1-8$ 
Samuelson, Paul A dan William Nordhaus. (2015). Makro Ekonomi. Edisi ke-17. Jakarta: PT. Media Global Edukasi.

Smith, C., (2010), “ Stock Markets and Exchange Rates: A Multy-Country Approach", Jurnal Riset Ekonomi dan Bisnis, vol.3 no.3 September
Tandelin, Eduardus, (2012) Pasar modal Indonesia: Problem dan Prospek. Wahana, volume 3 , No.2

www.bi.go.id

www.idx.co.id 